\title{
Efficacy of informal peace committees to peacebuilding: Evidence from Seke district, Zimbabwe
}

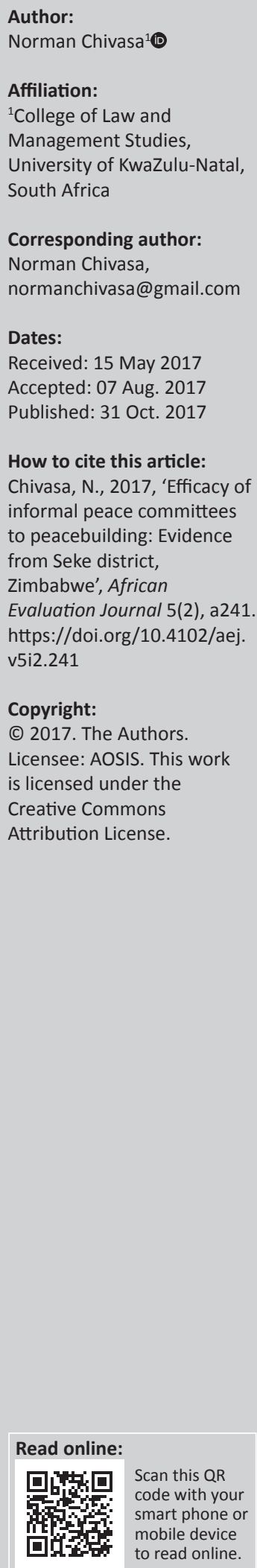

Background: In recent years, informal peace committees have rapidly made their mark either as precautionary or as response mechanisms to particular conflicts. Their main purpose is to prevent the eruption or escalation of nascent micro-level conflict into violent and more widespread conflicts. This article reports on aspects of a larger research project in which the researcher collaborated with local communities to create a ward-level peace committee in ward 8 of Seke district, Mashonaland East province, Zimbabwe.

Objective: To test whether and under what conditions informal peace committees can effectively help to contribute to peacebuilding at local community level.

Method: The study applied participatory action research to design, implement and evaluate the peace committee initiative with 15 individual members in ward 8 of Seke district. The study first conducted a 10-member focus group. Secondly, a follow-up in-depth interview on five focus group members and seven more involved in peacebuilding provided feedback on the effectiveness of informal peace committees.

Results: The study showed that creating informal peace committees is possible, as community participation in the design, implementation and day-to-day operations of such initiatives guarantees their sustainability even without external funding. One of the comparative advantages of informal peace committees is that all social groups in the community have equal chances of being represented, thus helping to meet the needs and aspirations of the community at large. The study further revealed that informal peace committees are faced with a number of limitations. The major one is that they do not enjoy official recognition from government, in spite of their critical role in contributing to peace in their host communities.

Conclusion: The strengths of informal peace committees are that they are self-initiated; they represent the interests of the host community and can be replicated.

\section{Introduction}

Between 2014 and 2015, I had the privilege of collaborating with local people in ward 8 of Seke district, Mashonaland East province in Zimbabwe. The goal of this collaborative work was to create a ward-level peace committee. Our peace committee initiative was not novel in Zimbabwe because many pro-peace donor-funded civil society organisations (CSOs) (such as Zimbabwe Civic Education Trust, Heal Zimbabwe Trust, Ecumenical Church Leaders Forum, and Envision Zimbabwe) were already involved in setting up peace committees both in rural and urban communities. For example, Heal Zimbabwe Trust created peace committees in Birchenough Bridge district, Buhera West and South districts in Manicaland province, Gokwe district in Midlands province, Muzarabani district in Mashonaland Central province and Zaka district in Masvingo province (Heal Zimbabwe Trust 2015). Envision Zimbabwe (2015) has collaborated with communities to create peace committees in Hurungwe district in Mashonaland West province and elsewhere. Zimbabwe Civic Education Trust (2014) also collaborated with communities across the 10 provinces. The irony is that many of these peace initiatives rely on donor-funded programmes. Therefore, to continue with the programme, the CSOs must follow the donor's template. As such, communities are at the risk of programme discontinuity once donor-funds run out. This article reports on collaborative work between local communities in Seke district and myself in creating a ward peace committee (WPC) initiative without the involvement of any external organisation.

The study is part of a larger research project, which was designed using participatory action research (PAR) to examine the possibility of informal peace committees to contribute to peacebuilding in Seke district, Mashonaland East province, Zimbabwe. The purpose of the study 


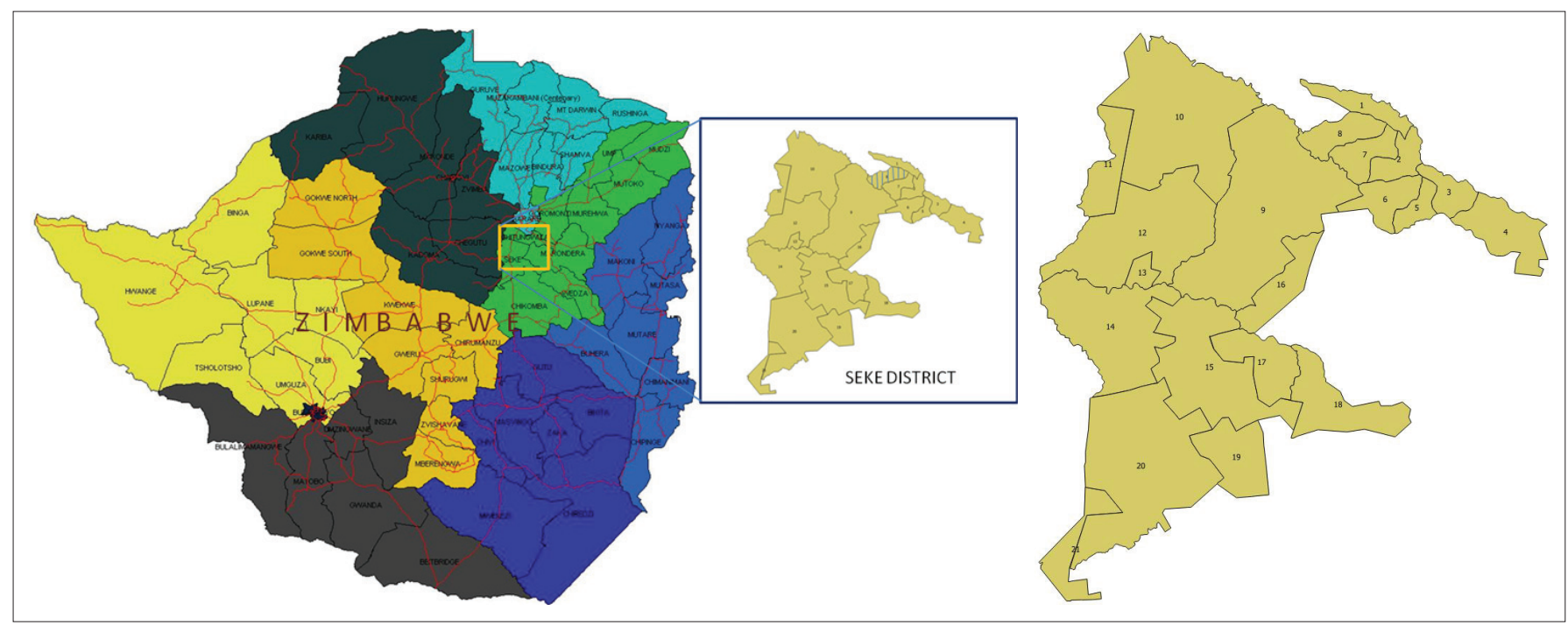

Source: Drawn by Ntozini Robert

FIGURE 1: Seke district wards map, including ward 8.

was to set up a ward-level pilot peace committee in order to establish whether informal peace committees can be an effective response to peace challenges bedevilling rural communities in Seke district. The central objective of this study was to examine the extent to which informal peace committees can effectively contribute to peacebuilding, taking Seke district as a point of reference. The paper is structured as follows: the 'Background and study locale' section describes the context and study location. The 'Peacebuilding theory' section reviews peacebuilding theory. The 'Literature review' section reviews literature on community formations and the comparative advantages of peace committees over other formations. The 'Research process' describes the data collection procedures. The 'Results and discussion' presents and analyses data. The 'Concluding remarks' sums up the entire study.

\section{Background and study locale}

Arguably, Zimbabweans are currently faced with erratic income streams because of instability in the economic sector (Nyakwawa 2015:3). FinScope Zimbabwe (2011:2) reported that about $61 \%$ go without cash at some stage, while $36 \%$ skip a meal because of lack of money or food. Fowler and Panetta (2010:2) noted that agriculture, which forms the basis of food production especially for the majority of rural people in Zimbabwe, has declined sharply because of persistent droughts and economic crises over the past decades affecting food production. From their perspective, decline in food production with attendant poverty and hunger has propelled some rural people to devise alternative livelihood strategies.

Poverty in rural wards in Zimbabwe is more widespread than in urban wards. For example, statistics indicate that the poverty prevalence rate in rural wards stands at $85 \%$ while the poverty prevalence in urban wards is at $37.2 \%$ (United Nations Children's Fund (UNICEF) 2015:xiii). Seke district is one of the districts that has not been spared by the scourge of poverty either. It is one of the nine districts in Mashonaland
East province, as shown in Figure 1. Seke is one of the precolonial rural districts, which was associated with the native inhabitants popularly known as the Hera people who are predominantly Shona speaking (Holleman 1952). The researcher is a native Shona, and is not only familiar with villages in Seke district but has lived and intimately shared experiences in the district on a regular basis since 1997.

Seke district has 21 wards comprising communal (wards 1-8) and commercial (wards 9-21) wards (see Figure 1). On average, the poverty prevalence in all 21 wards in Seke district stands at $56.0 \%$ with ward 21 being the hardest hit experiencing 70\% poverty levels (UNICEF 2015:76). Crop production is the primary means of livelihood in Seke district. This study was conducted in ward 8, a communal area, which largely relies on subsistence farming (crops and livestock). Crops include maize, groundnuts, sweet potatoes, small grains (such as millet), cow peas and beans. Proximity to Harare and Chitungwiza markets has propelled market gardening involving crops such as tomatoes, onions and other vegetables grown as cash crops providing livelihoods for households. To supplement their daily household consumption, residents rear traditional chickens, goats and cattle (Chivasa 2015:233-235).

Globally, poverty and hunger are some of the major determinants of conflict in the home and communities (Vanmeenen 2010:20). A previous study by Chivasa (2015:244245,275 ) showed that in ward 8, rural women have organised themselves into groups to address poverty and hunger under the aegis of the village savings and loan associations (VSLA) schemes. The scheme is accessed by more than 500 women and men in ward 8 alone, not to mention other wards in the district. In the study, peace challenges in ward 8 include but are not limited to hunger and food insecure households, unavailability of finances to pay school fees, rape cases involving the girl child, domestic violence, stock theft, robbery, theft, fighting and disputes over land boundaries (Chivasa 2015:304). The need for a peacebuilding framework 
that helps to address and prevent these types of conflicts in the home and communities as and when it arises was the impetus for this study to set up a peace committee in ward 8 of Seke district. The peace committee framework has a comparative advantage of extending the conflict resolution capacities of individuals and groups in ward 8.

\section{Peacebuilding theory}

The coinage of the term peacebuilding has been a momentous development in the history of humankind, notably since the end of the Second World War (Galtung 1976:297-298). By definition, peacebuilding signifies the idea that peace is more than just the absence of violence, but constitutes a dynamic positive state of affairs that needs to be built and reinforced (Chivasa 2015:12). In the last 25-plus years following the traction of peacebuilding in international policy and practice by Boutros Boutros-Ghali, in his capacity as Secretary-General of the United Nations, two peacebuilding frameworks have stood out as having a remarkable impact on the broad spectrum and trends of peacebuilding processes.

One such peacebuilding framework was the Infrastructure for Peace (I4P) in the 1990s, which approached peacebuilding as an integrated process requiring strategic designs in order to address all the facts surrounding conflict and the capacity to create an enabling environment that sustains peace (Lederach 1997:20). This framework marked the development of an understanding of conflict not only as an event or as mere conflictual behaviour but conflict as a system. As a system, conflict came to be understood as behavioural and attitudinal and a systemic phenomenon involving a number of interconnected elements such as context, history and actors (Lederach, Neufeldt \& Culbertson 2007:4), thus placing heavy emphasis on the need for comprehensive and allencompassing peace architecture to ensure sustainable peace. I4P also brought relief and changed the fortunes of the entire globe in relation to violent conflict, as the framework buttressed the design and establishment of peace-enhancing structures as a set of peacebuilding blocks. In many respects, the I4P framework planted the seed for a broader view of peacebuilding, which came to be understood not only as a 'science but an art, where imagination and creativity are an essential part of peacebuilding process' (Reychler 2002:26, 27)

The other such peacebuilding framework is the Local Peace Committees (LPC) as mechanisms for peace processes at local and national echelons (Sangqu 2014:422). This framework emerged in the 1980s (Giessmann 2016:9) after several decades of failed or at best limited peacebuilding achievements under the prevailing peacekeeping paradigm across the globe. By definition, an LPC is 'an inclusive forum operating at district, town or village in which stakeholders take a joint responsibility to build peace within their community' (Odendaal 2010:6). The arrival of the LPC mechanism was seen as the precursor to a new era in peacebuilding processes, which held promise over the prevailing peacekeeping paradigm, but its espousal and utilisation, as some authorities found out (for example,
Odendaal 2008:24, 2010:6; Van Tongeren 2012:108), remained limited especially at community level because contemporary peacebuilding frameworks are more predisposed to elite structures as opposed to being grassroots-driven.

From the 1990s onwards, many countries that experienced violent conflict yielded to demands for the need to establish local peace-enhancing structures to address peace challenges in their contexts. The creation of LPC frameworks in the aftermath of violent conflict is true in countries such as Nicaragua, South Africa, Kenya, Northern Ireland, Guyana, Ghana, Colombia and Sierra Leone (Kumar \& De la Haye 2011:15-17; Odendaal 2010:26-67). The informal peace committee (PC) framework is the central focus of this study.

\section{Literature review \\ Community-based formations}

Literature on community-based formations demonstrates that informal PCs are not the only self-initiated formations that villages have created (Chivasa 2015:292). In Zimbabwe, each village has a customary court and village and development committee (VIDCO), periodically elected by the village assembly (Government of Zimbabwe, 1998). The village head, a hereditary position, leads both the VIDCO and the village customary court. As such, there are possibilities that elected village assembly members can live in fear of the village head because his or her tenure usually outlasts that of other VIDCO or customary court office bearers. As Shih (2003:49) puts it, 'a village assembly, legally composed of all adults within a village, seemed at times powerless to make any decisions [which go against the interests of the village head]'. In that sense, one of the challenges facing the VIDCO is that given that the village head is the custodian of settlement permits for every adult in the host village, members serving as delegates in the VIDCO cannot override the decisions of the village head.

Although, there are some similarities between informal PCs and VIDCOs, there are also major differences as well. VIDCO is an elected developmental-oriented structure with responsibility for addressing challenges faced by villages such as underdevelopment, clean water and health issues (Stewart, Klugman \& Helmsing 1994:5). VIDCOs work hand in glove with ward development committees (WADCOs). One of the major developmental focus areas of the VIDCO is to promote incomegenerating projects at village or ward levels. Such structures work closely with the village community worker (VCW), a government employee under the ministry of Community Development in the case of Zimbabwe. This is one of the marked differences with informal PCs, which are accountable to the local community, not the government (Chivasa 2015:293).

Another community-based formation is the VSLA scheme. Informal PCs and VSLA schemes have some basic elements in common. The major similarities are that, in the first place, both employ the self-selection process as is often the case with VIDCOs, customary courts and WADCOs. Self-selection 
occurs when a community elects a committee in order to advance community interests and needs and, as such, there is leeway for some individuals to make requests to occupy certain positions. Self-selected individuals are obliged to conform to the norms and values of the community (Cox \& McCubbins 2004:34-35).

Secondly, both VSLA schemes and informal PCs involve men and women, but women predominate in the VSLA schemes (Bouman 1995:375; Vanmeenen 2010:1). Third and last, both formations are informal, and VSLA schemes do not enjoy official recognition from registered financial institutions. As for informal PCs, they do not receive official recognition from the mainstream I4P instituted by the incumbent government (Chivasa 2015:278).

In terms of creation, informal PCs differ significantly from VIDCOs and customary courts as these formations are created in terms of the Traditional Leaders Act (Chapter 29:17) and therefore enjoy official recognition from local government. VSLA schemes, although they remain informal, do have laid out procedures (Vanmeenen 2010:15).

In contrast, the creation of informal PCs demonstrates a process that is dynamic, flexible and adaptable because there are no laid down rules (Lederach 1997:84; Odendaal cited in Sangqu 2014:423). The unavailability of clear procedures is one of the challenges of the self-selection model, especially with reference to informal PCs, as there are no standardized ways of administering the creation of committees. Sangqu (2014:423) noted that when creating informal PCs, communities 'identify individuals, who have a vision for peacebuilding; who enjoy the trust of their communities; and who have the aptitude to build peace.' The strength of informal PCs is that the norms and values that regulate their operations in host communities are culture specific (Huyse \& Salter 2008:7; Van Tongeren 2013:40). Thus, the availability of non-formal structures demonstrates that peace is not a preserve of the elites. In other words, stakeholders that promote peace cannot be limited to a certain number.

Literature on informal PCs (for instance, Van Tongeren 2010:6, 2011:23, 2012:108, 2013:40) demonstrated that in communities where incumbent governments have proved incapable of providing basic services such as food and health and education services, the creation of informal PCs has provided a safety blanket for such communities. This is true of informal LPCs in Afghanistan, Colombia, Democratic Republic of Congo (DRC), Kenya, South Sudan and Uganda (Adan \& Pkalya 2006:3; Van Tongeren 2012:108, 2013:41-51). In all aspects at the community level, informal PCs seem to deliver on the hopes and expectations of mitigating violent conflict and in promoting socio-economic development initiatives that can contribute to the reduction of poverty, and improve livelihoods and peaceful co-existence.

In order to test whether and under what conditions the informal LPC intervention can help to promote peacebuilding,
I collaborated with community members in ward 8 of Seke district to create a ward-level peace committee between 2014 and 2015.

\section{The comparative advantage of informal peace committees as a peacebuilding tool}

Literature on informal PCs demonstrates they are a subcategory of the I4P. There are two things that can be said in that regard. The first is that a woman or a man can chair an informal PC and there are no restrictions on women in the decision-making processes. Secondly, conflicts in the villages can be settled amicably by working in collaboration with the various stakeholders, such as elders, women's groups, youth, Zimbabwe Republic Police (ZRP) or religious groups at the community level (Chivasa 2015:23). It is clear that informal PCs have the potential to harness all groups of people in the communities that are affected by conflict and violence (Envision Zimbabwe 2015) and these trends and patterns are not found in VSLA schemes, VIDCOs or customary courts.

As for VSLA schemes, they are predominated by women, and men are in the minority. In the case of households, villages and chief's courts, they remain the preserve of male kin members and acquaintances, and women and youth do not have an active role in decision-making processes. These trends and patterns continue to exist and are indeed a threat to peace at community level and are compounded by traditional gender roles, which do not accord equality between men and women (Moyo n.d.:90). Yet, Envision Zimbabwe advises that, 'when conflict and violence occur, it affects men, women, youth and children differently. Women and the girl child are the most affected by conflict' (2015). In that sense, the non-active participation of women and youth in customary courts is an impediment to sustainable peacebuilding at local community levels.

The comparative advantage of informal PCs over customary courts is that these structures take into account the diverse needs of vulnerable and marginalized groups, such as women and youth, as failure to include these vulnerable groups can be an incentive for a doomed peacebuilding process (Dhungana et al. 2007:xv). Accordingly, informal PCs create spaces for both women and youth to play an active role in peacebuilding processes because they harness men alongside such vulnerable and marginalized groups.

Overall, informal PCs address conflict because people live with conflict in the villages. For example, peace challenges in ward 8 include poverty, hunger and food insecure households, unavailability of finances to pay school fees, rape cases involving the girl child, domestic violence, stock theft, robbery, fist-fighting at beer parties and disputes over land boundaries (Chivasa 2015:304). In view of these circumstances, communities in Seke district need an inclusive framework representing the needs of all social groups to help address and prevent emerging and ongoing peace challenges. The propensity to represent all constituencies found in the community, such as 'civil servants, church leaders, traditional 
leaders, state security sector actors, political party leaders, women, youth and other stakeholders such as organisations operating at the community level', was seen by Moyo (n.d.:93) as a contributing factor to the sustainability of peace committees over other formations.

To interrogate informal PCs systematically, this study was instrumental in creating a WPC in Seke district and addressed the questions of whether and under what conditions an informal PC can be an effective peacebuilding mechanism. The creation of an informal PC was made possible by the fact that the current study was predominantly participatory from the design stage through to implementation and evaluation.

\section{Research process}

The central objective of this study was to examine the contributions of informal PCs to peacebuilding using participatory methodology. PAR methodology was considered appropriate because it has some similarities with peacebuilding. Both PAR and peacebuilding bring people together to address common problems and are relationshiporiented. Peacebuilding acknowledges that peace is no accident and requires planning, commitment, the participation of relevant stakeholders and cooperative relationships, all critical components in PAR. In other words, to achieve peace, individuals and groups need to form partnerships because peace is a result of group efforts and networks between stakeholders (Maruta 2008:7). Another reason for the choice of PAR was that trust, networks and social justice are all values that underpin both PAR and peacebuilding and are major components for peaceful communities (Van Niekerk \& Van Niekerk 2009:133).

In the first place, PAR was useful in linking research with action to bring about social change. Although PAR is not the only research design that could have been employed, its capacity to bring stakeholders together made it suitable for the current study, which sought to bridge research and action in order to improve or create a new practice (Whyte 1991:8), involving the creation of informal PCs in ward 8 of Seke district.

Letts et al. (2007:4) argue that PAR 'involves individuals and groups researching their own personal beings, socio-cultural settings and experiences. They reflect on their values, shared realities, collective meanings, needs and goals.' In the current study, PAR meant that local members of the community participated in the design and creation of the informal PC while I facilitated the process.

Furthermore, participatory methodology was useful because members of the community participated from the design stage through to evaluating their own activities. This participatory process ensured that if the intervention was to be rejected or accepted by the community that was to be done upfront. Thus, the participatory nature of the process ensured ownership of the intervention by the community, and the greater the involvement of the community in all facets of the intervention the more the community would be predisposed to carrying the intervention forward. Thus, the peace committee was set up by members of the community themselves using a self-selection process (procedures for setting up peace committees are still works in progress). Self-selection occurs when members of the community participate in picking individuals with culture specific qualities to occupy certain positions in a committee (Cox \& McCubbins 2004:33).

Accordingly, the WPC comprised 15 self-selected members. A steering committee of seven was created on the day of the information meeting, and I was appointed secretary ${ }^{1}$ of the committee. A ward is an administrative unit with membership drawn from villages (Kurebwa 2015:104) and it is under the leadership of a politically elected councillor. Ward 8 of Seke has 29 villages. As mentioned already, the WPC was made up of representative members from 10 neighbouring villages.

In terms of sectoral composition, the WPC comprised two ministers of religion, one businessperson, the ward councillor, a representative of the ministry of women's affairs and community development working in the ward, a representative of the ministry of youth working in the ward, the village head, the neighbourhood police officer, a Zimbabwe African National Union (ZANU) political party member, ${ }^{2}$ one retired army officer, a self-help area coordinator, three subsistence farmers and myself. Of the 15 WPC members, 14 had participated in a three-day conflict resolution workshop conducted in May 2013, at Murisa township in ward 8 . Eight were women while seven were men. Regarding employment, four were formally employed; the rest relied on informal mechanisms to eke out a living. As regards educational status, one had a degree, three had diplomas and the rest had attained primary-level education. Their ages ranged from the mid-40s to late 60s. All peace committee members became partners in the current research through the design, implementation and evaluation stages of the peace committee (participatory evaluation of the peace committee is still work in progress).

In order to maintain a participatory approach, the interview or focus group guide was a result of collaborative work between the WPC chairperson, the deputy chairperson and myself. Our task was to identify key areas that needed to be addressed in determining the efficacy of the WPC. Other members of the WPC were interviewed informally, after which I had a further meeting with the chairperson of the WPC to discuss some themes that I picked from informal At first, I was appointed deputy chairperson but declined and opted for the position of secretary, knowing ahead that I was going to be involved in writing minutes, doing member checking to validate the minutes and to remind all members of any up-coming events or meetings. I was prepared to take up this responsibility. The chairperson and the entire team agreed that I take up this position. Requesting to occupy certain positions is in line with the self-selection process, which the wouldbe group adopted.

2.At one point, we discussed the issue of inclusivity of the peace committee and whether it should include both ZANU (PF) and Movement for Democratic Change whether it should include both ZANU (PF) and Movement for Democratic Chang (MDC) members and we noticed that some me were ZANU(PF) were not for the idea of having MDC members become stakeholders in the same peace committee. After considering the pros and cons that came out of this discussion, we resolved that a WPC should first be created and then issues of inclusivity could be dealt with gradually as we go. 
discussions with WPC members. Under the chairperson's mandate, I compiled a set of questions around these thematic areas: goals, effectiveness, creation and limitations of peace committees. In the first, second and third rounds of interviews, we reviewed these thematic areas in preparation for the focus group discussion with the entire group of members of the WPC. We finally settled on these four discussion questions:

- What do you consider as the main goals of peace committees?

- What have you found useful about the peace committee in promoting peace?

- From your experience, who should be involved in setting up peace committees?

- What would you consider as limitations associated with informal peace committees?

The chairperson of the WPC facilitated these discussions and, as the secretary, I was responsible for recording what transpired. Of the 15 members of the WPC, only 12 (seven women and five men) attended the focus group discussions. For the purposes of validating data from participants, during discussions I was at liberty to do member checking on certain issues, which were inconclusive.

As these discussions were conducted within the confines of the WPC's normal routine of monthly meetings, prior consent from participants to use an audio voice recorder to record proceedings was obtained. I alternated voice recording with writing notes, especially noting non-verbal cues that could not be captured by the voice recorder.

Discussions during monthly meetings and interviews were held in a mixture of Shona and English. This was also true of the WPC focus group discussions. As the WPC comprised of individuals with prior contacts before becoming committee members, the atmosphere during weekly and monthly meetings appeared normal for almost every member of the peace committee. As all the meetings were conducted in our native language, for purposes of this study, I engaged an experienced translator who assisted in translating from Shona to English.

After data collection, I transcribed data while it was still fresh in my mind to ensure that the context in which the conversation and discussion occurred was not lost along the way. In fact, data transcription was ongoing over a period of nine consecutive monthly meetings. With the help of an audio voice recorder, transcription of data was made possible immediately after collection. As mentioned, after every meeting I had to transcribe all the information collected during a WPC meeting in preparation for the next WPC meeting. Thus, listening to a voice recorder for purposes of transcribing data almost became a norm for the nine months that I served as secretary of the WPC. My routine interaction with data helped me to link words with what transpired during peace committee meetings and events that I observed, thus enhancing credibility and trustworthiness on the findings. After transcribing data from the discussions, I was at liberty to conduct follow-up interviews with four individuals, including two who attended and two who had not attended the focus group discussions. For the purposes of this study, I treated these interviewees as stakeholders in peacebuilding rather than just informants, because of their active involvement in peace issues at village level. Through these interviews, I was able to fill some gaps in the data and seek clarity on some ideas, particularly from those who had attended the discussions. I compiled all the results separately (data from the focus group and from the four interviews) and presented them to the WPC. I did this to allow the WPC to decide on some similarities and divergences in these two sets of data.

Regarding data analysis, it was twofold; the initial analysis involved discussions by the WPC after which I was able to identify themes. The WPC was involved in the analysis of data, in line with Bloor et al. (2001:13) who advised that stakeholders who participated in the design and implementation of an initiative are justified in analysing the data. Krueger (1994:153) contended that these individuals [WPC or stakeholders] have had first-hand exposure to each of the discussions, observed the interactions ... and likely have had the most intensive exposure to the problem'. Thus, the WPC was justified in analysing data.

In the second but last stage of the analysis, as the creation of a peace committee had an academic component requiring me to produce a report, I reflected on and compared the findings by the WPC with reviewed literature for possible links and divergences.

After gaining an understanding of peace committees in ward 8 of Seke district, I endeavoured to solicit the perspectives of individuals with experience in setting up peace committees in other communities in Mashonaland East province for three major reasons. Firstly, I was eager to know the experiences of other people beyond Seke district. Secondly, it became clear to me that the phrase 'peace committees' has received a fair share and was fairly well-understood at the grassroots level, but little attention in empirical research had focused on Mashonaland East province. Lastly, yet importantly, I had the desire to increase the scope of the study on the experiences of peace committees in communities. Nonetheless, individual narratives on experiences of peace committees in particular, participants whose stories have been captured in this document, seem not to have gained scholarly attention up to this point. In addition, I purposively selected two individuals based on their active involvement in creating peace committees in Goromonzi district, Mashonaland East province, and asked them to narrate their lived experiences. These stakeholders were not members of the WPC. After they shared their experiences, I saw no reason to conduct further interviews after realising that I was getting the same information. In total, participants in this study amounted to16 stakeholders, (14 WPC members by sector plus two narrators) as shown in Table 1. To protect their confidentiality and privacy, I have used the title stakeholders throughout the report. Accordingly, research findings presented in this article are a combination 
TABLE 1: Composition of stakeholders who participated in the current study.

\begin{tabular}{llll}
\hline Number $(N=16)$ & Representation by sector & Age group & Sex \\
\hline $1(n=1)$ & Village head & Late 50s & Female \\
$2(n=1)$ & Defence forces & Early 50s & Male \\
$3(n=1)$ & Community health worker & Mid 40s & Female \\
$4(n=2)$ & Subsistence farmer & Early 60s & Female \\
& Subsistence farmer & Late 40s & Female \\
$5(n=2)$ & Minister of religion & Mid 40s & Male \\
& Minister of religion & Mid 50s & Male \\
$7(n=1)$ & Traditional healer & Early 70s & Female \\
$7(n=1)$ & Business forum & Late 40s & Male \\
$8(n=1)$ & Neighbourhood Police officer & Mid 40s & Male \\
$9(n=1)$ & Councillor & Early 50s & Male \\
$10(n=1)$ & Youth & Early 30s & Female \\
$11(n=1)$ & Ward political commissar & Mid 40s & Female \\
$12(n=1)$ & Youth & Late 20s & Female \\
$13(n=1)$ & Community worker & Early 50s & Male \\
$14(n=1)$ & Community worker & Mid 40s & Male \\
\hline
\end{tabular}

Source: Chivasa, Fieldwork 2015

of the first preliminary results from focus group discussions, interviews and analysis made by the WPC at our regular monthly meeting and my analysis, which involved a component on the review of related literature.

Overall, the continual collaborative process involving the researcher and the WPC was verified by the analysis of data at various stages of the process. For example, WPC members verified data collected through formal meetings, and stakeholder interviews and stakeholder focus group discussions verified participant observations. The results incorporate insights from 14 WPC members, two narrators in Goromonzi district and the researcher.

The identification of themes for discussion was made possible when I devised a coding system technique. Bless and HigsonSmith (1995) advise that letters or symbols could be used to represent data in the form of codes. In the current study, I employed a data coding system called pattern coding in which I assigned letters to distinguish themes. For example, themes relating to peace committees as precautionary measures I coded this as PM, cost effectiveness as CE, ownership and sustainability of peace committees as $\mathrm{SO}$, replicability as $\mathrm{R}$ and limitations as LIM. Those themes that recurred more frequently I considered as major themes and the rest as sub-themes.

\section{Results and discussion}

All participants ${ }^{3}$ demonstrated that the phenomenon of peace committees was not new to them. However, they were very clear that peace committees are response mechanisms that contribute significantly to peacebuilding in the community. They identified peace committees as precautionary or response measures to conflict in the home or community. They also concluded that ownership, sustainability and replicability are fully guaranteed particularly for peace committees that are self-initiated by communities.

3.Members of the peace committee involved individuals from Murisa, Chikambi Chitehwe, Vera, Kuwora, Masona, Madhovi, Matambo and Marimbi villages, and two stakeholders from Gormonzi district.

\section{Peace committees as a precautionary or response measure}

All participants indicated that peace committees are forums created before or after a conflict has emerged. They stressed that a peace committee can be created as a precautionary measure but also as a direct response to a particular conflict, in which case its main purpose is to prevent the eruption or escalation of nascent micro-level disputes into violent and more widespread conflicts. Moyo (n.d.:92) pointed out that LPCs are 'a practical response to ensure peace prevails'. One participant aptly summed up this view:

'Efforts at community levels have been directed at building local peace committees in conflict-ridden and conflict-prone communities in many parts of Zimbabwe. These structures are formed either as a reaction to a particular conflict, in which case their main purpose is to contribute to the management of the conflict and to post-conflict peacebuilding.' (Community worker, mid 50s, male)

His view resonates with studies by Van Tongeren (2012:107) that found that when state fragility occurs, the creation of informal LPCs helps communities to address peace challenges affecting their well-being. Supportively, Odendaal (2010:37) and Sangqu (2014:423) contended that communities create peace committees to advance their interests. Moyo (n.d.) made similar points when he said:

LPCs build peace in their communities through creating dialogue spaces where people engage each other in search of solutions to their challenges. They also facilitate peacebuilding sessions. In some situations, they mediate conflict and act as early warning systems and work towards addressing human security concerns in their areas. (p. 93)

In saying this, Moyo suggested that by creating peace committees, communities are taking responsibility for their own peace. As results seem to indicate, the main purpose of a peace committee is to prevent the eruption or escalation of nascent micro-level disputes into violent and more widespread conflicts. This is true of Zimbabwean communities, because ever since electoral violence in 2008, in all aspects at the community level, informal peace committees seem to deliver on the hopes and expectations of mitigating violent conflict and promoting socio-economic development initiatives that can contribute to the reduction of poverty. As the literature demonstrated, the inclusive nature of peace committees representing all social groups, including the vulnerable such as youth and women, makes them relevant and timely to build peace at community level.

\section{Cost-effectiveness}

From hands-on experience, it became clear that the setting up of peace committees involves a number of logistical issues (physical and economic). However, participants claimed that self-initiated peace committees are less expensive because of their reliance on available resources in the community. In general, participants were very clear that the issue of cost effectiveness relates to the amount of time spent looking for venues, monetary issues, mobilisation of people, 
effectiveness of gate keepers, acceptability of the initiative in the community and its work. They emphasised that compared to peacebuilding projects run directly by an external agency, a LPC is relatively less expensive. One participant expressed similar sentiments:

'Peace committee can secure free venues, or at least low-cost or discounted, by virtue of the fact that they are a communitybased formations rather than an non-governmental organization (NGO) that is usually perceived as outsiders and to have a lot of money; in addition, they can easily use existing community infrastructure because it is theirs too. Thus if the peace committee is carried out by the local formation, it would cost far less in direct expenses.' (Minister of religion, early 50s, male)

Securing free venues as was the case in ward 8 of Seke district was already an indication of acceptance of the peace committee by members of the larger community. The treatment given to informal peace committees by the community and those created by donor-funded civic organisations indicates that communities consider selfselected structures as formations that advance their interests. In that same discussion, another participant claimed that:

'There is a cost reduction benefit to be enjoyed if the local formation is given a leading role in the planning and implementation of project activities. The point here is that when the money is available, it should be spent more at the local level by the local peace committees involved; when money is short, the work should still continue as most of it does not require direct expenditure.' (Community worker, mid 50s, male)

In another discussion, all participants accepted the notion that peace committees initiated by local people themselves are effective in terms of their day-to-day operations and execution of their duties. One informant elaborated this view further when he said:

'When it comes to local protocol, local peace committees are the best. This involves liaising with the local authorities and other organisations working in the area, mobilising participants from among the local population, and organising venues and supplies among other things. Members of the local peace committee know who to contact and when, and the procedures to follow in order to get the best results. Such seemingly mundane issues as knowledge of the village head's totem and how to praise-sing it becomes crucial at times. The members are also better placed to return either if the person being sought is not available at the time of the initial visit, or if the issues need further deliberation at a later time. The peace committee members involved in these logistics can make some of these visits in the course of their daily routines and therefore do not have to spend extra money specifically for the transaction in question. Thus they easily level the ground for the work, and lubricate the process.' (Community health worker, early 40s, female)

Studies by Lederach (1997:50) have demonstrated that what makes peace committees effective is the fact that most if not all are situated in existing networks (involving village heads, local councillors, chiefs and other leaders), particularly those created by community members themselves. Any peace committee that utilises these networks has the potential to build peace at local community levels. These existing networks have proved viable and have made a marked difference elsewhere, as the literature demonstrated, in contributing to peace in communities. The representation of all social groups or constituencies found in the community, including vulnerable groups such as youth and women, offers peace committees a platform conducive to creating co-existence and cohesion.

\section{Ownership and sustainability of peace committees}

Regarding ownership and sustainability of peace committees, participants claimed that peace committees are sustainable because they are part of the everyday life of the members and for the rest of the community. They stressed that peace committees are not overly affected by the extremes of availability or lack of donor funding. In principle, this means therefore that the effectiveness and sustainability of the peace committee are not compromised significantly. This is particularly the case with all self-initiated peace committees, as another informant confidently remarked:

'Because peace committees are formed of ordinary members of the community, they are organically blended into the community, even though they may not have achieved wide acceptance at a given point in time. This is because they are part of the everyday life of the community, especially in rural areas where every going-on gets to be known by everyone around, not least the village head. Furthermore, with particular reference to the rural areas, no outside organization carries out a project without the express authority of the local traditional authority who often asks his/her people if they want the project before giving his/ her final word.' (Councillor, mid 50s, male)

Most participants approved that outsiders cannot simply set up a peace committee in the villages without the approval of leaders of the community and the general populace. They emphasized that this lack of consent is not the case with selfinitiated peace committees. In an interview, one informant summed up the issues of ownership of the peace initiative by saying:

'While this local ownership and sustainability might happen of its own accord, often it has to be planned for and built into the process at the formation stage. There are at least two negative forces at play here militating against automatic ownership and sustainability. The first, is the donor syndromeaspiring members of the peace committee must be told that they will work on a voluntary basis and that they will pay a fee to join and remain members of the peace committee. This would help to drive home the point that they will be expected to give before they can receive. This giving, whether in cash or kind, can be a strong motivator for them to own and carry on with the project through thick and thin. It will also motivate them to give their all - energy, creativity, time, etc. - to make the project a success. Enemy number two is selfishness. Today some people are so bent on immediate gratification, victims of the 'what is in it for me now' syndrome that they will not participate in anything that does not promise to yield a clear, tangible and immediate benefit for them with little or no investment in cash, time or effort. While self-preservation is a natural instinct, most of the human progress recorded in history, whether at the individual or collective level, has been 
founded on self-interest, which is in a sense constructive selfishness.' (Community worker, mid 50s, male)

At another time, this community worker advised:

'Thus members of peace committee must be made to appreciate the need and importance of achieving their goals by putting others first, through strategically calculated service to others, in whatever they do. That is, they should swap selfishness for selfinterestedness.' (Community worker, mid 50s, male)

Overall, all participants emphasised that ownership is a thorny issue. It became clear that if individuals who already know each other well create a peace committee, sustainability is fully guaranteed. This was true of the WPC in ward 8 of Seke district. I was resident in ward 8 of Seke district and I had regular contacts with individuals I cooperated with in the creation of the peace committee. Thus, my entry into the social space to set up a peace committee occurred within the context of prior contacts with all WPC members. I had interacted with some members of the WPC in different social and religious forums prior to sharing the social space as co-researchers. From this experience, I realised that creating a peace committee is achievable when the initiative is situated within an already existing network of prior contacts. Ownership and sustainability becomes automatic when community members participate in the process from the design phase to implementation of the initiative. One informant put to rest the issue of ownership and sustainability by saying:

'If community participates or not in the process, the peace committee is rejected or accepted up front. And if it is accepted, the more the peace committee works in the community, with the community and for the community, the more the community co-owns its work and is predisposed to carry it forward with or without the participation and/or support of the external agency that might have initiated it.' (Councillor, mid 50s, male)

To this end, it can be argued that the self-selection process becomes critical because it gives the community the opportunity to participate in the design and ownership of the initiative (Cox \& McCubbins 2004:33).

\section{Replicability}

On the question of whether informal PCs can be replicated or not, participants claimed that when communities take the responsibility to set up a peace committee replication is obvious. They understood replication as a process akin to vegetative reproduction or to seed dispersal as in plant species whether wild or domestic. One informant expressed similar sentiments:

'People from non-participating communities, having somehow come into contact with peace committees, have been known to request to have similar formations in their communities. A different way of dispersion is where a member of the peace committees in question migrates to another community and works to establish a similar committee in the new community. Another possibility is where a member of a committee wants a similar structure in a community where a relative or friend lives and asks the relative or friend to set up one in that community and assists him/her to that end. Naturally, however, it is the initiating organization that plays the lead role in establishing new peace committees in new communities.' (Ward political commissar, mid 40s, female)

To corroborate another informant remarked that:

'Peace committees have the potential to reach every community in every corner of the community. In doing so, it might very well touch a significant size of the population of the community in one way or another, especially since every person in the country belongs to at least one community. In that respect, it can contribute to peacebuilding and reconciliation at national level.' (Neighbourhood police officer, mid 40s, male)

The theme of replication of peace committees is prominent in the literature. For example, Adan and Pkalya (2006:13) argued that in Kenya, the Wajir peace and development committees were started by a group of local women and traditional elders but later on were replicated in other districts in Kenya. Odendaal (2010:40) noted that in Kenya, by 2001, 2005 and after electoral violence between 2007 and 2008, informal peace committees were replicated under government sanction in other parts of the country to help prevent further escalation of violence.

Similarly, in the Philippines, a group of community members established the first peace formation in September 1988 in Naga city. Subsequently, there were other peace formations in the Philippines in places such as Sagada in November 1988; Tabuk in April 1989; Bituan in November 1989; and Cantomanyog in February 1990 (Avruch \& Jose 2007:52). Such evidence indicates that peace committees can be replicated. However, to get them replicated, communities should participate in the design and operations of the initiative in order to produce their own kind elsewhere. The reality of replicability occurred in ward 8 of Seke district, in which the WPC reproduced itself forming five more village peace committees (VPCs) after a 16-village tour in which villages were sensitized to consider setting up VPCs. Responsibility to create these VPCs was put in the hands of village heads to ensure legitimacy in the host village (see Chivasa 2015:303).

\section{Limitations faced by informal peace committees}

Although peace committees are effective and sustainable, participants strongly stressed that they often do not have the capacity to deal directly with political level conflicts. Using their experiences in Zimbabwe, they stressed that this limitation is especially noticeable during election time when political polarisation in communities takes centre stage. Of greater concern by all participants was that even peace committees formed mainly of members of different political parties are often found wanting during election times. One participant summed it up by saying:

'This paralysis is mainly due to the fact that these types of conflicts are usually instigated from outside of the community by people at a higher level within the political formations 
involved, such that the local political functionaries merely follow orders. Yet the lower level social conflicts that the local peacebuilding formations often deal with contribute to the political stability or otherwise of the community as they are the fodder on which the political polarization feeds. Thus the more effective they are at the lower levels of social interaction and relationships the more relevant their work becomes at the higher levels in the community.' (Community worker, mid 50s, male)

However, in the literature, the identified limitations of peace committees differ significantly from those identified by participants. In the literature, it was demonstrated that informal peace committees face collapse because of lack of funding (Van Tongeren 2012:107). A classic example in Zimbabwe was the Zimbabwe Civic Education Trust (ZIMCET) peace committee programme, which survived a near collapse because of lack of funding until Oxfam America and other well-wishers rescued the organisation in 2003. From this example, it is clear that peace committees run on funded programmes are at risk as some members participate based on what they will get out of the peace programme rather than what they are likely to contribute (ZIMCET 2014). To mitigate this limitation, support should be offered to self-initiated peace committees to ameliorate their legitimacy.

Another limitation is that informal PCs are restricted in taking part in the peace process. Sangqu (2014:423) pointed out that peace processes have been largely dominated by the elites who include political leaders and international stakeholders. She noted that, currently, informal PCs were situated to address 'the softer aspects of peace process' [i.e., reconciliation, forgiveness and healing-related issues] and concluded that such a position has ripple effects on the critical role of informal PCs in peacebuilding. However, she contended that while peace processes cannot be left to political elites alone, and noted that informal PCs should not play a subordinate role but should actively collaborate in the peace process. Further, she recommended that attempts should be made by elites to give space to informal PCs to participate actively in the entire peace process but warned that informal PCs should operate independent of elites, if trust, legitimacy and social cohesion are to be harnessed.

In addition, in some countries such as Zimbabwe, peace committees do not have any legal framework because their establishment followed an informal model in which people at the grassroots were involved in setting up the initiative. In such a context, the challenge is that informal PCs do not enjoy official recognition from the state and therefore they often suffer setbacks in terms their inclusion in mainstream peacebuilding (Odendaal 2010:40).

Finally yet importantly, another limitation is that of power dynamics associated with peace committees in their host communities. Moyo (n.d.:92) notes that if the community is male-dominated, the composition of the peace committee will be influenced by these gender dynamics, thus posing a challenge to gender representation on the committee. Adan and Pkalya (2006:15) pointed out that, although peace committees drew much of their approaches from both customary and cosmopolitan norms and values, the challenge is traditional practices that have not been opening up, especially in those areas involving the inclusion of women, youth and political leaders. The exclusion of women and youth serves only to reinforce the patriarchal system in communities, which embraces tradition (Odendaal 2010:40). This challenge can be mitigated if the principle of inclusivity, which undergirds peace committees, is embraced. In the WPC in Seke district, although the chairperson is male, the woman who is the deputy is also the chairperson for the projects team within that same WPC. She holds strategic positions in various civic organisations working in Seke, namely, the area coordinator for Shamwari yemwanasikana and Virl Microfinance, the deputy chair for Child Protection Unit, and is involved in facilitating burial societies in Seke. At a political level, she is the ward political commissar in the ruling party. These attributes indicate that she is very influential in the ward and also in the peace committee. The inclusive nature of peace committees is to ensure that power is balanced in terms of decision-making, planning and implementation across the various stakeholders in peace issues.

\section{Concluding remarks}

This article demonstrates that informal peace committees are responsive mechanisms created by local people to take responsibility for their own peace. In doing so, this study reflected on the efficacy of informal PCs created through collaborative work between members of the community in ward 8 of Seke district and myself. The WPC comprised 15 members (eight women and seven men) who came together to set up a peace-enhancing structure using the self-selection process. Resulting from hands-on experience of working with the WPC as a member of the advisory team in ward 8 in Seke district, this study concludes that community peace initiatives are often small and simple, yet effective and sustainable. They are small in that they do not involve official bureaucratic structures, but are local structures that are developed from within the community. Such initiatives are usually guided by culture specific cultural norms and values and that is what makes them more informal but legitimate in their host communities. The strengths of community-led initiatives are that they address the community's basic needs and challenges and can be replicated.

While the results of this study cannot be generalized for all communities across the globe, it is important to note that some aspects of the results, in particular those involving the issue of sustainability of informal LPCs at village level, have a universal application. This is so because, as the findings have shown, this study makes the point that sustainability of community-led initiatives will always be guaranteed by the level of participation and ownership by the host community whether rural or urban. Participation by members of the village is not context specific and it can be applied across communities. However, variables such as social norms and 
values are context specific because they vary from one village to another. Thus, any community willing to take responsibility for its own peace can find these results helpful particularly on issues to do with participation and ownership in creating peace committees or any other community-based formation.

\section{Acknowledgements Competing interests}

The author declares that he has no financial or personal relationship(s) which may have inappropriately influenced him in writing this article.

\section{References}

Adan, M. \& Pkalya, R., 2006, A snapshot analysis of the concept peace committee in relation to peacebuilding initiatives in Kenya: Practical action, CORDAID, Nairobi.

Avruch, K. \& Jose, R.S., 2007, Peace zones in the Philippines, Kumarian Press, Chicago, IL.

Bouman, F.J.A., 1995, 'Rotating and accumulating savings and credit associations: A development perspective', World Development 23(3), 371-384. https://doi. org/10.1016/0305-750X(94)00141-K

Bless, C. \& Higson-Smith, C., 1995, Social research method: An African perspective, Juta, Cape Town.

Bloor, M., Frankland, J., Thomas, M. \& Robson, K., 2001, Focus groups in socia research, Sage, London.

Chivasa, N., 2015, 'Peacebuilding among Shona communities in transition: A participatory action research', Unpublished PhD thesis, University of KwaZuluNatal, Durban.

Cox, G.W. \& McCubbins, M.D., 2004, 'Legislative leviathan', viewed 07 August 2015, from http://investigadores.cide.edu/aparicio/refpol/Cox\&McCubbins_Legislative Leviathan_book06.pdf

Dhungana, S.K., Bharadwaj, N.N., Crozier, R. \& Hicks, N., 2007, 'Voices from the villages: Peoples' agenda for peace' friends for peace and International Alert, Kathmandu, November', viewed 03 August 2017, from http://www.internationalalert.org/sites/default/files/publications/voices_from_the_villages_cover.pdf

Envision Zimbabwe, 2015, Building bridges, viewed 23 June 2015, from www.envision. org.zw

FinScope Zimbabwe, 2011, FinScope consumer survey Zimbabwe 2011, Finmark Trust viewed 28 October 2016, from www.zimstat.co.zw/sites/default/files/img/ publications/Finance/FinScope.pdf

Fowler, B. \& Panetta, D., 2010, AKF savings group learning initiative, AGA Kkan Development Network, Geneva, viewed 28 October 2016, from www.akdn.org

Galtung, J. (ed.), 1976, Peace, war and defense: Essays in peace research, Christian Ejers, Copenhagen.

Giessmann, H.J., 2016, Embedded peace infrastructures for peace: Approaches and lessons, Berghof Foundation, Berlin, viewed 03 August 2017, from http://www. berghof-foundation.org/fileadmin/redaktion/Publications/Other_Resources/ UNDP_21768_-_Doc_1_-_Embedded_Peace_2016.pdf

Heal Zimbabwe Trust, 2015, Peacebuilding, viewed 19 July 2015, from http://www. fmcw.org/uploads/peacebuilding.pdf

Holleman, J.F., 1952, Shona customary law, Oxford University Press, Cape Town.

Huyse, L. \& Salter, M. (eds.), 2008, Traditional justice and reconciliation after violent conflict: Learning from African experiences, International Institute for Democracy and Electoral Assistance, Stockholm.

Krueger, R.A., 1994, Focus group: A practical guide for applied research, Sage, London.

Kumar, C. \& De la Haye, J., 2011, 'Hybrid peacemaking: Building national infrastructure for peace', Global Governance 18, 13-20.

Kurebwa, J., 2015, 'A review of rural local government system in Zimbabwe from 1980 to 2014', Journal of Humanities and Social Sciences 20(2), 94-108.

Lederach, J.P., 1997, Building peace: Sustainable reconciliation in divided societies, Institute of Peace Press, Washington, DC.
Lederach, J.P., Neufeldt, R. \& Culbertson, H., 2007, Reflective peacebuilding: A planning monitoring and learning toolkit, The Joan B. Krock Institute for International Peace Studies and Catholic Relief Services Southeast, viewed 03 August 2017, from https://ndigd.nd.edu/assets/172927/reflective_peacebuilding a_planning_monitoring_and_learning_toolkit.pdf

Letts, L., Wilkins, S., Law, M., Stewart, D., Bosch, J. \& Westmorland, M., 2007, Guidelines for critical review form: Qualitative studies (Version 2.0), Qualitative Review Form Guidelines, pp. 1-12, viewed 03 August 2017, from https://srsmcmaster.ca/wp-content/uploads/2015/05/Guidelines-for-Critical-Review-FormQualitative-Studies.pdf

Maruta, S. (ed.), 2008, 'Hands-on community peacebuilding, democracy and development in Zimbabwe', in Proceedings of the Symposium on Community Peacebuilding, Democracy and Development, Epworth near Harare, October 22, viewed 03 August 2017, from https://books.google.co.zw/books/about/Hands on_Community_Peace_building_Democr.html?id=4k2xQwAACAAJ

Moyo, A., n.d., 'Community-based healing and reconciliation in Zimbabwe', viewed 04 April2015, from http://www.storiesofhumansecurity.net/documents/130967769/ 130987562/GPPAC Publicatie_Human+Security_Zimbabwe.pdf/255036f7-4ff441c7-96bd-136a51cb7a1a

Nyakwawa, G.M., 2015, 'Mobile money savings helping the bottom of the pyramid to save in Zimbabwe', viewed 18 October 2016, from http://www.slideshare.net/ MunyaradziGeraldNyak/mobile-money-savings-helping-the-bop-to-save-inzimbabwe

Odendaal, A., 2008, 'Local peacebuilding forums: Rationale and methodological hypotheses', UNDESA-DPADM and BCPR Ad Hoc Expert Group Meeting on Reconstructing Governance and Public Administration Capacities for Conflict Prevention and Development, Accra, 2-4 October, viewed 03 August 2017, from http://unpan1.un.org/intradoc/groups/public/documents/ un/unpan032127.pdf

Odendaal, A., 2010, An architecture for building peace at local level: A comparative study of local peace committees, A discussion paper, The Bureau for Crisis Prevention of the United Nations Development Programme, viewed 03 August Prevention of the United Nations Development Programme, viewed O3 August
2017, from http://www.un.org/en/land-natural-resources-conflict/pdfs/UNDP 2017, from http://www.un.org/en/land-natu
Local\%20Peace\%20Committees_2011.pdf

Reychler, L., 2002, 'Peace architecture', Peace and Conflict Studies 9(1), 24-35.

Sangqu, S., 2014, 'A crucial link: Local peace committees and national peacebuilding', African Security Review 23(4), 422-424. https://doi.org/10.1080/10246029.2014. 956472

Shih, V., 2003, 'Political efficacy in rural China: An exploration of villager attitude toward village assemblies and village committees in four counties', American Asian Review XXI(4), 45-68.

Stewart, F., Klugman, J. \& Helmsing, A.H., 1994, Decentralization in Zimbabwe, Occasional paper 15, viewed 03 August 2017, from http://hdr.undp.org/sites/ default/files/frances_stewart.pdf

Government of Zimbabwe, 1998, Traditional Leaders Act, Chapter 29:17, Act 25/1998, modified by S.I. 430A/1999,22/2001, Government Printers, Harare.

United Nations Children's Fund (UNICEF), 2015, Zimbabwe poverty atlas: Small area poverty estimation, UNICEF, World Bank, ZIMSTAT, Harare.

Vanmeenen, G., 2010, Savings and Internal Lending Communities (SILC): Voices from Africa, Catholic Relief Services, East Africa Regional Office, viewed 03 August 2017, from savings-revolution.com/doclib/SILC $\% 2$ Voices $\% 2$ from $\% 20$ Africa. pdf

Van Niekerk, L. \& Van Niekerk, D., 2009, 'Participatory action research: Addressing social vulnerability of rural women through income generating activities', JAMBA: Journal of Disaster Risk Studies 2(2) November, 127-144. https://doi.org/10.4102/ jamba.v2i2.20

Van Tongeren, P., 2010, Infrastructure for peace, Working paper, GPPAC, viewed 01 July 2015, from en.nai.nl/mmbase/.../Infrastructures_for_PeaceWPMarch10 without_annex.pdf

Van Tongeren, P., 2011, 'Increasing interest in infrastructures for peace', Journal of Conflictology 2(2), 16-26.

Van Tongeren, P., 2012, 'Creating infrastructures for peace: Experiences at three continents', Pensamiento Propio 36-37, 91-128.

Van Tongeren, P., 2013, 'Potential cornerstone of infrastructures for peace? How local peace committees can make a difference', Peacebuilding 1(1), 39-60. https://doi. org/10.1080/21647259.2013.756264

Whyte, W.F., 1991, Participatory action research, Sage, London.

Zimbabwe Civic Education Trust (ZIMCET), 2014, Peace committee concept, viewed 31 October 2014, from http://.www.zimcet.org 